\title{
Advanced Alcalase-Coated Clindamycin-Loaded Carbopol Nanogels for Removal of Persistent Bacterial Biofilms
}

\author{
Paul J. Weldrick, ${ }^{+a}$ Shirley San, ${ }^{+a}$ and Vesselin N. Paunov*a \\ ${ }^{a}$ Department of Chemistry and Biochemistry, University of Hull, Hull, HU6 7RX, UK \\ † Both authors contributed equally to this manuscript. \\ *Corresponding author: Email: V.N.Paunov@hull.ac.uk
}

(ACS Applied Nano Materials 2021) 


\section{Supporting Information}

\begin{tabular}{|c|c|}
\hline Contents & Page \\
\hline Background Information: Antimicrobial Agents & $3-4$ \\
\hline $\begin{array}{l}\text { The mean particle size, zeta potential and electrophoretic mobility comparison various NP } \\
\text { formulations }\end{array}$ & 5 \\
\hline $\begin{array}{l}\text { TEM images of } 0.1 \text { wt } \% \text { "empty" Carbopol nanoparticles and } 0.1 \text { wt\% Carbopol Aqua SF1 } \\
\text { nanoparticles loaded with } 0.1 \text { wt } \% \text { clindamycin and coated with } 0.02 \text { wt } \% \text { Alcalase }\end{array}$ & 5 \\
\hline $\begin{array}{l}\text { The mean particle diameter and zeta potential of } 0.02 \mathrm{wt} \% \text { Alcalase- } 0.1 \mathrm{wt} \% \\
\text { Clindamycin- } 0.1 \mathrm{wt} \% \text { Carbopol }\end{array}$ & 6 \\
\hline Elemental analysis of the NPs pellet & 6 \\
\hline UV-Vis spectrum of Carbopol, Clindamycin and Clindamycin loaded Carbopol & 7 \\
\hline Clindamycin release kinetics in pH 5.5 and 7.5 solutions & 8 \\
\hline $\begin{array}{l}\text { Minimum inhibitory concentration (MIC) and minimum bactericidal concentration (MBC) } \\
\text { of NPs formulations on planktonic S. aureus }\end{array}$ & 8 \\
\hline S. aureus zeta potential & 8 \\
\hline $\begin{array}{l}\text { The percentage of residual biofilm mass after 24-hour treatment with Carbopol and } \\
\text { Alcalase. }\end{array}$ & 9 \\
\hline Quantification of FDA and PI staining of S. aureus biofilms & 9 \\
\hline Statistical analysis tables & $10-11$ \\
\hline References & $12-13$ \\
\hline
\end{tabular}




\section{Supporting Information}

\section{Background Information: Antimicrobial Agents}

Clindamycin hydrochloride was the antibiotic of choice for this study which we loaded in the selected Carbopol nanogel particles. Being a class of lincosamide antibiotics, ${ }^{1}$ clindamycin is related to lincomycin and are most effective against Gram-positive bacteria, including $S$. aureus, and can be bactericidal along with its capability of inhibiting and interfering with protein synthesis of targeted bacteria by binding onto the $50 \mathrm{~S}$ ribosomal subunits. ${ }^{1-4}$ However, the lethality and effectiveness of clindamycin is highly dependent on its concentration and its sensitivity. ${ }^{2}$ Clindamycin can be administered parenterally as well as orally and widely distributed across the body, including bones and organs ${ }^{5}$ but comes with side effects as skin burns and peeling, ${ }^{1}$ as well as rashes, ${ }^{5}$ gastrointestinal disturbance, hepatotoxicity and hypersensitivity. ${ }^{1}$

PVP-I is made up of polyvinylpyrrolidone which, acts as a carrier for free iodine. It is used as a bactericidal agent to clean wounds on skin, disinfecting hands or for the prevention of skin infections before and after surgery. ${ }^{6}$ The concentration of iodine delivered to infected parts of the body is dependent on the made-up solution. ${ }^{7}$ It is effective against a plethora of bacteria due to its ability to penetrate biofilms and remain a challenge for them to acquire crossresistance against this disinfectant. ${ }^{8}$ Despite its effectiveness, there have been reports on some adverse effects caused by treating an infection with PVP-I. This includes acute renal failure, hyperthyroidism, and metabolic acidosis. ${ }^{9}$ As well as this, there were also concerns raised on PVP-I's toxicity. ${ }^{8-10}$

Benzalkonium chloride (BKC) is another commercially used effective biocide against harmful microorganisms. ${ }^{11}$ However, due to growing concerns of allergic reactions upon usage ${ }^{12}$ and cases reported of bacteria becoming resistant to BKC, the use of this agent has been restricted. ${ }^{13}$ There have also been reports of adverse effects upon its usage, including disturbances in human neutrophil function and leukocyte responses towards sites of inflammation. ${ }^{14}$ Past studies have mentioned its toxicity in mammalian cells, ${ }^{15}$ however, it can be counter-argued that BKC is safe to use according to some reports. ${ }^{16}$

Chloroxylenol is used for disinfecting wounds on skin, sanitising surgical equipment as well as in household cleaning compositions. ${ }^{17}$ Due to its ionisable properties, ${ }^{18}$ it affects $S$. aureus cell membranes by increasing their fluidity and permeability. ${ }^{19}$ It has also been reported that they 


\section{Supporting Information}

can disrupt the function of proteins and enzymes, further increasing bacterial sensitivity to biocides. ${ }^{20}$ Regarding its mechanism of resistance against chloroxylenol, exact events remain unclear and unknown. However, there have been some reports of resistance against $P$. aeruginosa as well as some suggested resistance which are common among disinfectants and antiseptics including the formation of biofilms, mutations and cellular permeability. ${ }^{21,22}$

Cetrimide is another alternative antiseptic used for treating wound infections. It is a cationic surfactant and a derivative of quaternary ammonium salts, which are much more prone to resistance against bacteria compared to PVP-I and is reportedly toxic to epithelial cells. ${ }^{11}$ Studies have shown its effectiveness against Gram-negative and Gram-positive bacteria, ${ }^{23}$ as well as having a prolonged antimicrobial activity over time. 


\section{Supporting Information}

\section{Additional Results}

Table S1. The mean particle size diameter, zeta potential and electrophoretic mobility comparison of "empty" Carbopol, Carbopol-Clindamycin NPs, Alcalase, Alcalase-Carbopol NPs and Alcalase-Carbopol-Clindamycin NP formulations.

\begin{tabular}{|c|c|c|c|}
\hline Composition & $\begin{array}{c}\text { Particle Size } \\
\text { / nm }\end{array}$ & $\begin{array}{c}\text { ל-potential / } \\
\mathrm{mV}\end{array}$ & $\begin{array}{c}\text { Electrophoretic } \\
\text { mobility / } \\
\mu \mathrm{m} \mathrm{cm} \mathrm{V} \mathbf{~}^{-1} \mathrm{~s}^{-1}\end{array}$ \\
\hline 0.1 wt\% Carbopol (pH 5) & $102 \pm 0.4$ & $-48 \pm 0.2$ & -0.0015 \\
\hline 0.1 wt\% Carbopol (pH7.5) & $325 \pm 0.3$ & $-45 \pm 0.1$ & -0.0048 \\
\hline 0.025 wt\% Clindamycin-0.1 wt\% Carbopol (pH 5) & $120 \pm 0.6$ & $-44 \pm 0.3$ & -0.0056 \\
\hline 0.1 wt\% Clindamycin-0.1 wt\% Carbopol (pH 5) & $140 \pm 0.5$ & $-43 \pm 0.3$ & -0.0055 \\
\hline 0.005 wt\% Alcalase (pH 5) & $8.1 \pm 0.1$ & $20 \pm 0.2$ & 0.024 \\
\hline 0.005 wt\% Alcalase-0.1 wt\% Carbopol (pH 5) & $140 \pm 0.4$ & $19 \pm 0.2$ & 0.0065 \\
\hline 0.05 wt\% Alcalase-0.1 wt\% Carbopol (pH 5) & $148 \pm 0.5$ & $44 \pm 0.4$ & 0.0024 \\
\hline $\begin{array}{l}0.02 \text { wt\% Alcalase-0.1 wt\% Carbopol-0.1 wt\% Clindamycin } \\
\text { (pH 5) }\end{array}$ & $149 \pm 0.6$ & $34 \pm 0.2$ & 0.0043 \\
\hline
\end{tabular}
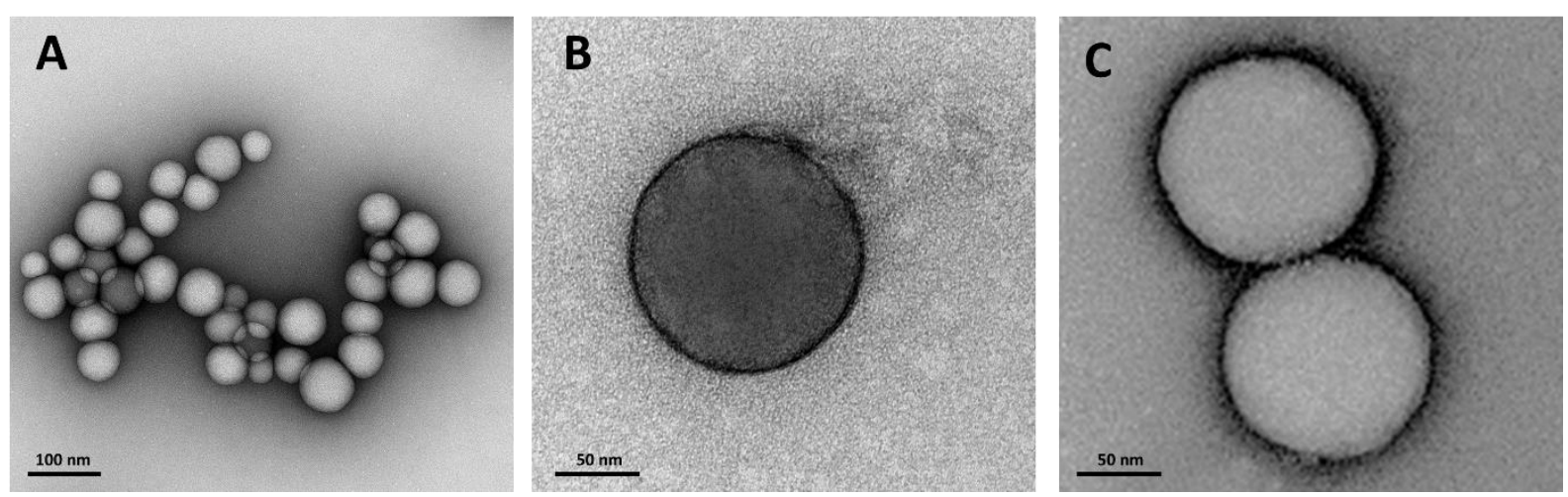

Figure S1. (A) TEM image of $0.1 \mathrm{wt} \%$ "empty" Carbopol nanoparticles. (B) Magnified TEM image of 0.02 wt\% Alcalase- 0.1 wt\% clindamycin-0.1 wt\% Carbopol nanoparticles and (C) magnified image of $0.1 \mathrm{wt} \%$ clindamycin-0.1 wt\% Alcalase nanogel (uncoated). All samples were counterstained in 1 wt \% uranyl acetate for 1 min during preparation. TEM images were obtained using a JEM 2010 (JOEL, Japan) at $120 \mathrm{kV}$ and a Gatan Ultrascan 4000 digital camera. 


\section{Supporting Information}
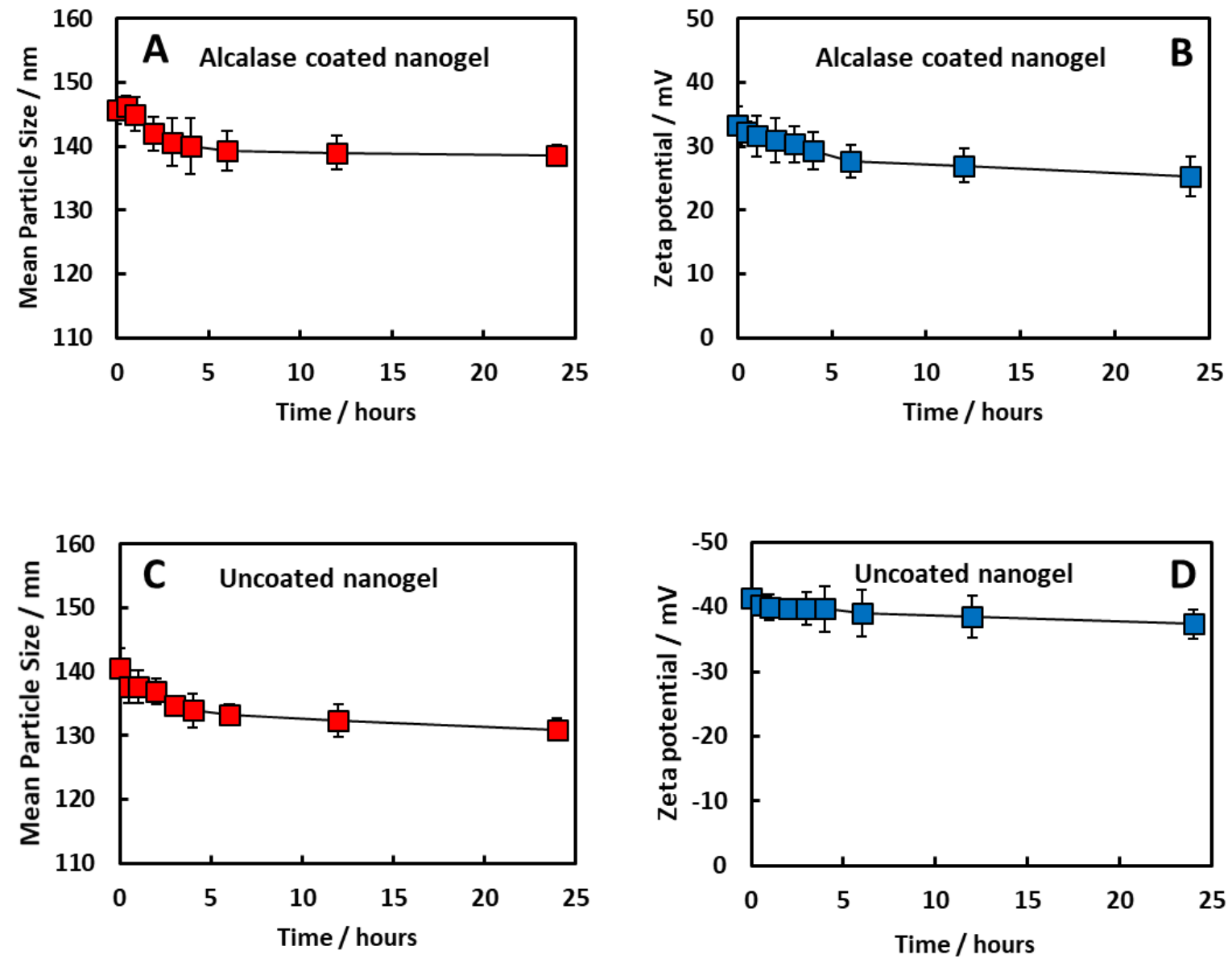

Figure S2. (A) The mean particle diameter and (B) zeta potential of $0.1 \mathrm{wt} \%$ Carbopol-0.1 wt\% clindamycin-0.02 $\mathrm{wt} \%$ Alcalase. (C) The mean particle diameter and (D) zeta potential of $0.1 \mathrm{wt} \%$ Carbopol-0.1 wt\% clindamycin (uncoated). All measurements taken at pH 5. The mean size and zeta potential of the Carbopol nanogel was measured using a Malvern Zetasizer with a R.I of 1.450 at $25^{\circ} \mathrm{C}$. Each value represents a triple replicate with \pm S. D. The lines are guides to the eye.

Table S2. Elemental analysis of the NPs pellet and individual components.

\begin{tabular}{|c|c|c|c|}
\hline Element & Carbopol & Clindamycin* & $\begin{array}{c}\mathbf{0 . 1} \text { wt\% Carbopol-0.1 } \\
\text { wt\% Clindamycin }\end{array}$ \\
\hline C & 38.45 & 50.22 & 46.87 \\
\hline H & 8.87 & 7.71 & 8.29 \\
\hline N & 0.69 & 6.33 & 5.65 \\
\hline S & 0 & 6.29 & 2.02 \\
\hline \multicolumn{2}{|c|}{ \% Clindamycin content in Carbopol NPs } & 26.83 \\
\hline
\end{tabular}

*Clindamycin - $424.98 \mathrm{~g} / \mathrm{mol}$. Calculation; $(2.02 / 32) * 424.98=26.83$ 


\section{Supporting Information}

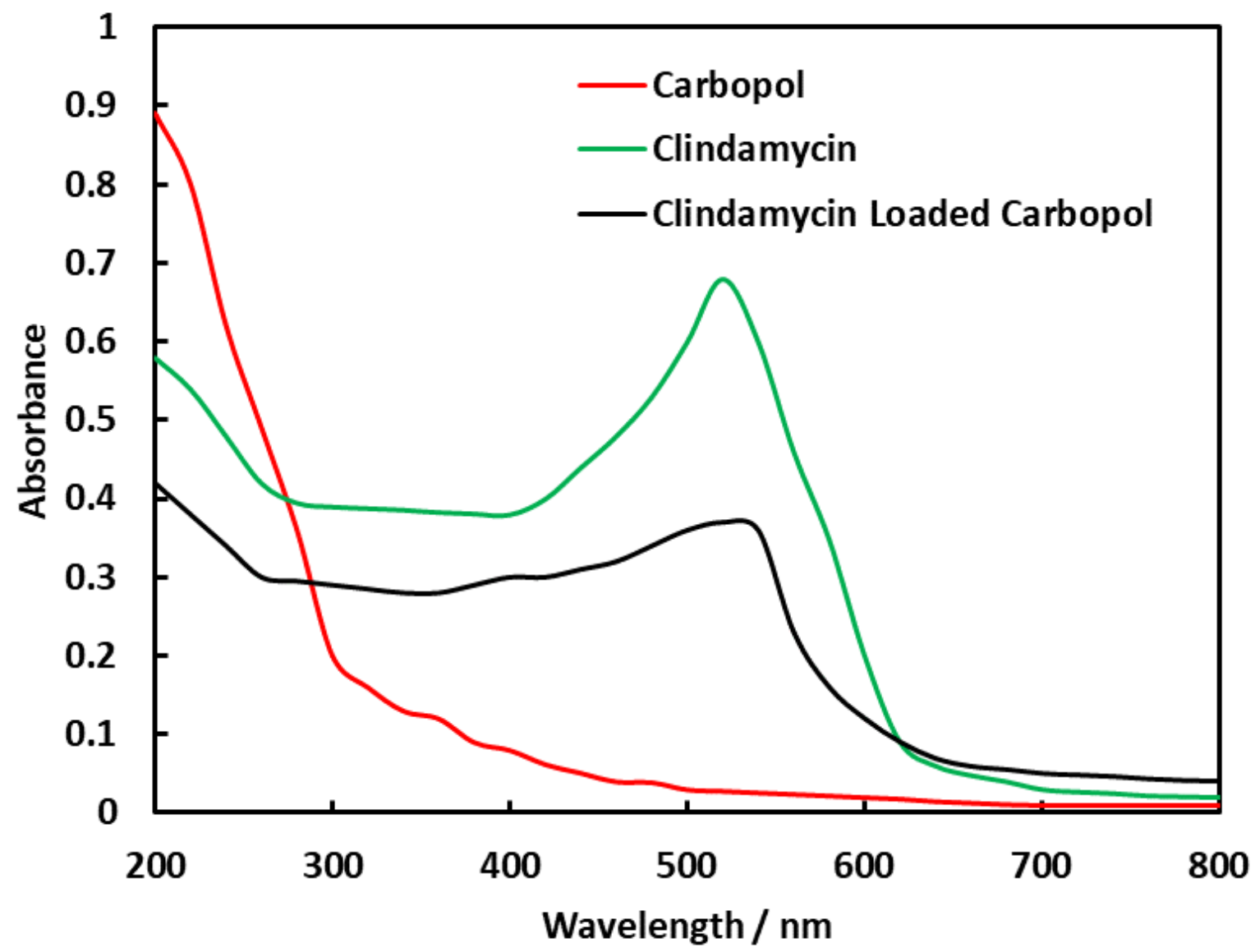

Figure S3. The UV-Vis spectrum of $0.1 \mathrm{wt} \%$ Carbopol (red line), $0.1 \mathrm{wt} \%$ Clindamycin (green line) and $0.1 \mathrm{wt} \%$ Clindamycin-loaded 0.1 wt\% Carbopol. All solutions were adjusted to pH 5.5 using acetate buffer. The absorbance was measured between 200 and $800 \mathrm{~nm}$ using a FLUOstar Omega spectrophotometer. 


\section{Supporting Information}
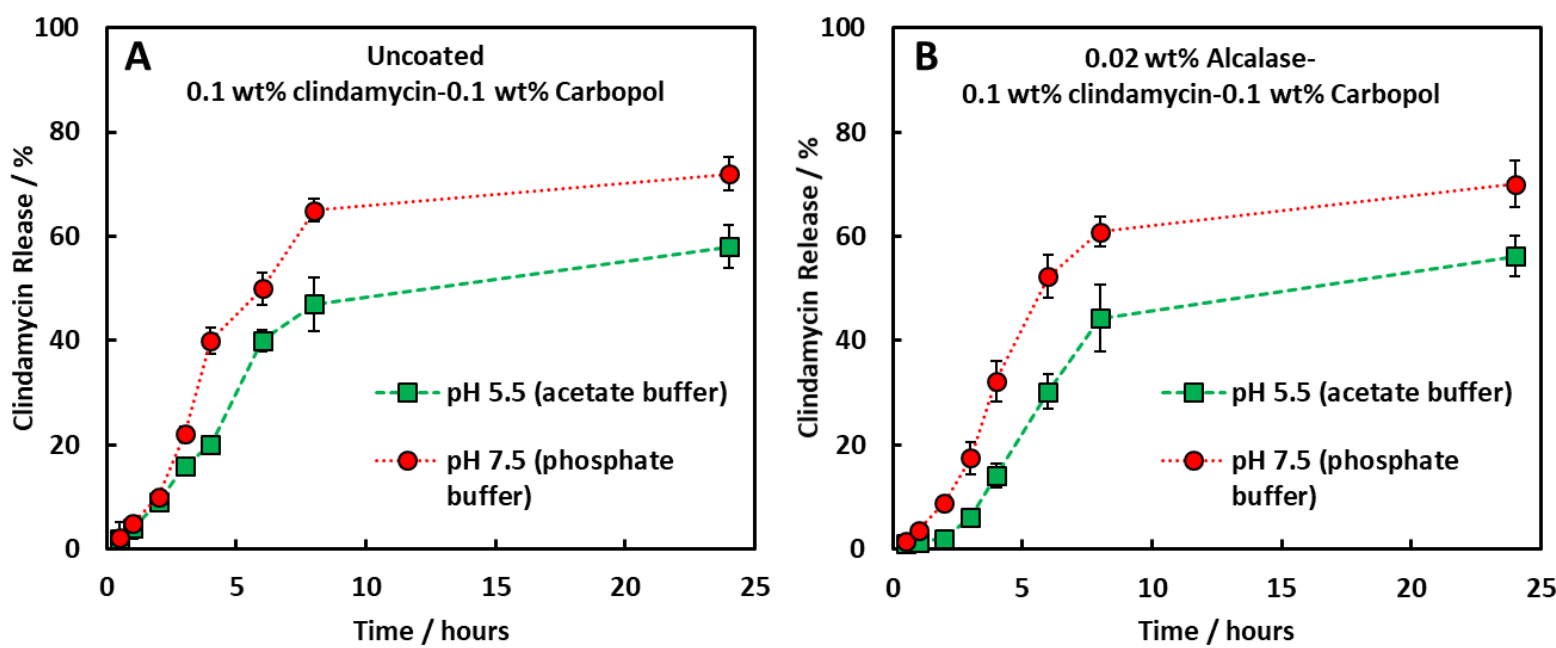

Figure S4. Clindamycin release kinetics in $\mathrm{pH} 5.5$ and 7.5 solutions. $10 \mathrm{~mL}$ of (A) 0.1 wt\% clindamycin- 0.1 wt\% Carbopol nanogel and (B) $0.02 \mathrm{wt} \%$ Alcalase-0.1 wt\% clindamycin-0.1 wt\% Carbopol suspension was placed into a 10-12 kDa MWKA dialysis bag and sealed with plastic clips. The bag was then placed into $250 \mathrm{~mL}$ of acetate or phosphate buffer ( $\mathrm{pH} 5.5$ and 7.5 respectively) and constantly stirred. $1 \mathrm{~mL}$ aliquots were removed at time intervals and the absorbance read at $540 \mathrm{~nm}$. The concentration of clindamycin in the buffer was interpolated using a clindamycin calibration curve.

Table S3. Planktonic S. aureus minimum inhibitory concentration (MIC) and minimum bactericidal concentration (MBC) of Carbopol, Alcalase, Clindamycin, and Alcalase-coated Clindamycin encapsulated Carbopol NPs (antibiotic concentration is shown). The lowest concentration of antimicrobial agent inhibiting/no growth was considered the MIC/MBC.

\begin{tabular}{|l|c|c|}
\hline Antimicrobial agent & \multicolumn{1}{|c|}{ MIC } & MBC \\
\hline Carbopol & $>1 \mathrm{mg} / \mathrm{mL}^{-1}(0.1 \mathrm{wt} \%)$ & $>1 \mathrm{mg} / \mathrm{mL}^{-1}(0.1 \mathrm{wt} \%)$ \\
\hline Alcalase & $1 \mathrm{mg} / \mathrm{mL}^{-1}(0.1 \mathrm{wt} \%)$ & $>2 \mathrm{mg} / \mathrm{mL}^{-1}(0.2 \mathrm{wt} \%)$ \\
\hline Clindamycin & $0.05 \mathrm{mg} / \mathrm{mL}^{-1}(0.005 \mathrm{wt} \%)$ & $0.1 \mathrm{mg} / \mathrm{mL}^{-1}(0.01 \mathrm{wt} \%)$ \\
\hline $\begin{array}{l}\text { Alcalase-coated Clindamycin encapsulated } \\
\text { Carbopol NPs }\end{array}$ & $0.006 \mathrm{mg} / \mathrm{mL}^{-1}(0.0006 \mathrm{wt} \%)$ & $0.01 \mathrm{mg} / \mathrm{mL}^{-1}(0.001 \mathrm{wt} \%)$ \\
\hline
\end{tabular}

Table S4. Zeta potential of S. aureus. The refractive index was 1.384 and the absorption was 1.000. $N=3$ with \pm S.D.

\begin{tabular}{|c|c|}
\hline Bacterium & 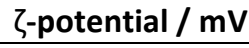 \\
\hline Staphylococcus aureus & $-21 \pm 0.37$ \\
\hline
\end{tabular}




\section{Supporting Information}

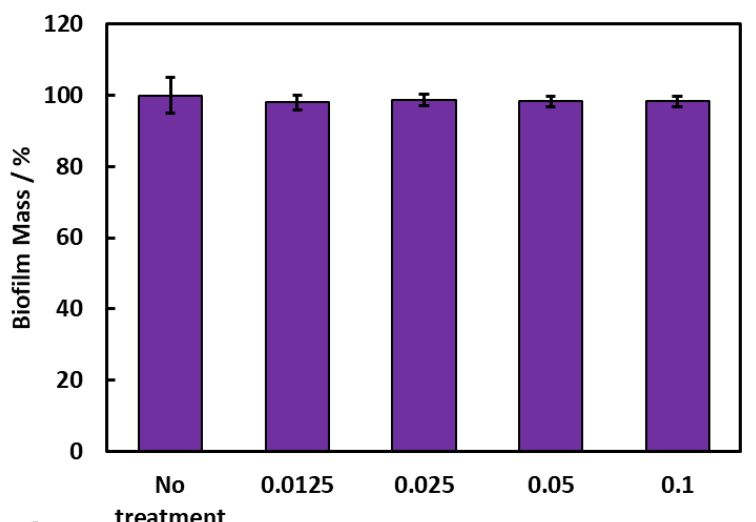

A

Carbopol / wt\%

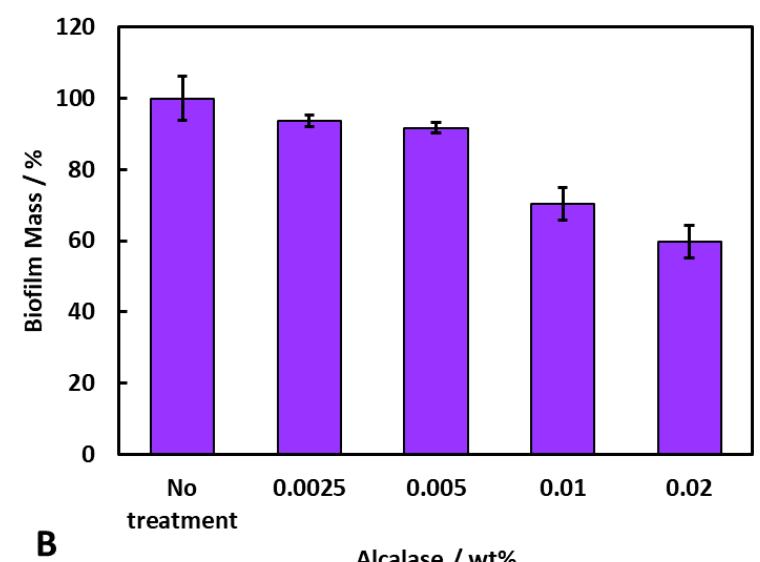

Figure S5. The percentage of residual biofilm mass after 24-hour treatment with (A) Carbopol and (B) Alcalase. The treatment was monitored over different time intervals from 30 mins, $1 \mathrm{~h}, 2 \mathrm{~h}$ and $24 \mathrm{~h}$ and are compared. Each value represents a triple biological repeat with $\pm \mathrm{S}$. D.

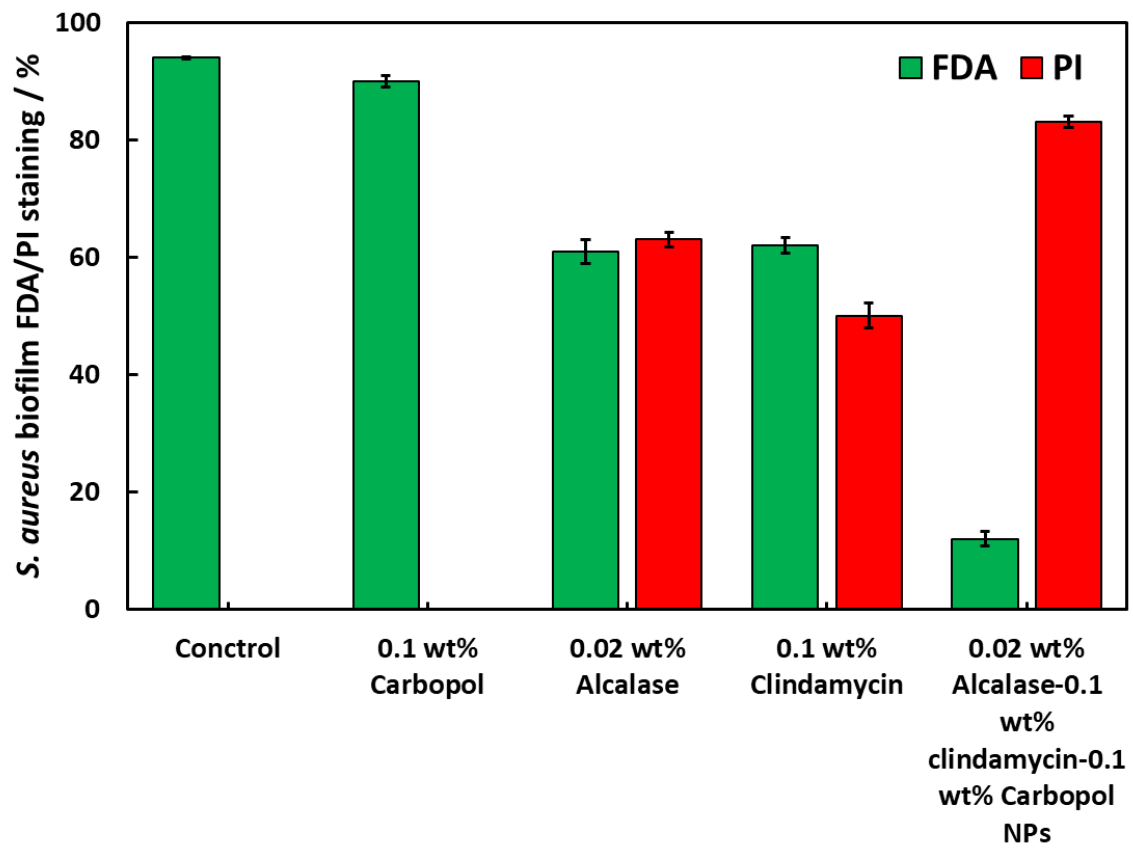

Figure S6. Quantification of FDA and PI staining of S. aureus biofilms treated for 24 hours. The relative fluorescent intensity \% of biofilm stained with FDA/PI was quantified using ImageJ v1.52d. 


\section{Supporting Information}

Table S5. Statistical analysis of equivalent concentrations of therapeutic agents vs stock 0.02 wt\% Alcalase-0.1 wt\% clindamycin- 0.1 wt\% Carbopol NP treatment on biofilm residual mass after 30 mins (figure 10A). Data were expressed as average values \pm standard deviations of the mean. P-values of less than 0.05 were considered significant. ${ }^{*} \mathrm{P}<0.05,{ }^{*} P<0.01,{ }^{* * *} P<0.001$. All Student's T-tests were performed in GraphPad v7.0.4.

\begin{tabular}{|l|c|c|c|c|c|c|c|}
\hline & $\begin{array}{c}\text { Mean 1 } \\
\text { (CLC) }\end{array}$ & $\begin{array}{c}\text { Mean 1 } \\
\text { (therapeutic } \\
\text { agent) }\end{array}$ & $\begin{array}{c}\text { S.D. of } \\
\text { Mean 1 }\end{array}$ & $\begin{array}{c}\text { S.D. of } \\
\text { Mean 2 }\end{array}$ & $\begin{array}{c}\text { Biological } \\
\text { repeat No. }\end{array}$ & P-value & Sig. \\
\hline $\mathbf{0 . 1}$ wt\% PVP-I & 15.3 & 84.8 & 0.06 & 0.34 & 3 & $<0.0001$ & $* * *$ \\
\hline $\mathbf{0 . 1}$ wt\% Citrimide & 15.3 & 83.3 & 0.06 & 0.77 & 3 & $<0.0001$ & $* * *$ \\
\hline $\begin{array}{l}\mathbf{0 . 1} \text { wt\% Benzylkonium } \\
\text { Chloride }\end{array}$ & 15.3 & 59.6 & 0.06 & 0.36 & 3 & $<0.0001$ & $* * *$ \\
\hline $\begin{array}{l}\mathbf{0 . 1} \text { wt\% } \\
\text { Chlorohexynol }\end{array}$ & 15.3 & 97.3 & 0.06 & 0.14 & 3 & $<0.0001$ & $* * *$ \\
\hline
\end{tabular}

Table S6. Statistical analysis of equivalent concentrations of therapeutic agents vs stock 0.02 wt\% Alcalase-0.1 wt\% clindamycin-0.1 wt\% Carbopol NP treatment on biofilm residual mass after $\mathbf{2 4} \mathbf{~ h}$ (figure 10A). Data were expressed as average values \pm standard deviations of the mean. P-values of less than 0.05 were considered significant. ${ }^{*} \mathrm{P}<0.05,{ }^{* *} P<0.01,{ }^{* * *} P<0.001$. All Student's T-tests were performed in GraphPad v7.0.4.

\begin{tabular}{|l|c|c|c|c|c|c|c|}
\hline & $\begin{array}{c}\text { Mean 1 } \\
\text { (CLC) }\end{array}$ & $\begin{array}{c}\text { Mean 1 } \\
\text { (therapeutic } \\
\text { agent) }\end{array}$ & $\begin{array}{c}\text { S.D. of } \\
\text { Mean 1 }\end{array}$ & $\begin{array}{c}\text { S.D. of } \\
\text { Mean 2 }\end{array}$ & $\begin{array}{c}\text { Biological } \\
\text { repeat No. }\end{array}$ & P-value & Sig. \\
\hline $\mathbf{0 . 1}$ wt\% PVP-I & 23.9 & 36.1 & 0.45 & 0.09 & 3 & $<0.0001$ & $* * *$ \\
\hline $\mathbf{0 . 1}$ wt\% Citrimide & 23.9 & 61.6 & 0.45 & 0.28 & 3 & $<0.0001$ & $* * *$ \\
\hline $\begin{array}{l}\mathbf{0 . 1} \text { wt\% Benzylkonium } \\
\text { Chloride }\end{array}$ & 23.9 & 31.4 & 0.45 & 0.14 & 3 & 0.0053 & $* *$ \\
\hline $\begin{array}{l}\mathbf{0 . 1} \text { wt\% } \\
\text { Chlorohexynol }\end{array}$ & 23.9 & 58.4 & 0.45 & 0.17 & 3 & $<0.0001$ & $* * *$ \\
\hline
\end{tabular}

Table S7. Statistical analysis of therapeutic concentrations of therapeutic agents vs stock 0.02 wt\% Alcalase-0.1 wt\% clindamycin-0.1 wt\% Carbopol NP treatment on biofilm residual mass after 30 mins (figure 10C). Data were expressed as average values \pm standard deviations of the mean. P-values of less than 0.05 were considered significant. ${ }^{*} \mathrm{P}<0.05,{ }^{* *} P<0.01,{ }^{* * *} P<0.001$. All Student's T-tests were performed in GraphPad v7.0.4.

\begin{tabular}{|l|c|c|c|c|c|c|c|}
\hline & $\begin{array}{c}\text { Mean 1 } \\
\text { (CLC) }\end{array}$ & $\begin{array}{c}\text { Mean 1 } \\
\text { (therapeutic } \\
\text { agent) }\end{array}$ & $\begin{array}{c}\text { S.D. of } \\
\text { Mean 1 }\end{array}$ & $\begin{array}{c}\text { S.D. of } \\
\text { Mean 2 }\end{array}$ & $\begin{array}{c}\text { Biological } \\
\text { repeat No. }\end{array}$ & P-value & Sig. \\
\hline $\mathbf{0 . 1}$ wt\% PVP-I & 15.22 & 44.3 & 0.06 & 0.31 & 3 & $<0.0001$ & $* * *$ \\
\hline $\mathbf{0 . 1}$ wt\% Citrimide & 15.22 & 39.8 & 0.06 & 0.34 & 3 & $<0.0001$ & $* * *$ \\
\hline $\begin{array}{l}\mathbf{0 . 1} \text { wt\% Benzylkonium } \\
\text { Chloride }\end{array}$ & 15.22 & 28.1 & 0.06 & 0.14 & 3 & $<0.0001$ & $* * *$ \\
\hline $\begin{array}{l}\mathbf{0 . 1} \text { wt\% } \\
\text { Chlorohexynol }\end{array}$ & 15.22 & 35.6 & 0.06 & 1.58 & 3 & $<0.0001$ & $* * *$ \\
\hline
\end{tabular}




\section{Supporting Information}

Table S8. Statistical analysis of therapeutic concentrations of therapeutic agents vs stock 0.02 wt\% Alcalase-0.1 wt\% clindamycin-0.1 wt\% Carbopol NP treatment on biofilm residual mass after 24 h (figure 10C). Data were expressed as average values \pm standard deviations of the mean. P-values of less than 0.05 were considered significant. ${ }^{*} P<0.05,{ }^{*} P<0.01,{ }^{* * *} P<0.001$. All Student's T-tests were performed in GraphPad v7.0.4.

\begin{tabular}{|l|c|c|c|c|c|c|c|}
\hline & $\begin{array}{c}\text { Mean 1 } \\
\text { (CLC) }\end{array}$ & $\begin{array}{c}\text { Mean 1 } \\
\text { (therapeutic } \\
\text { agent) }\end{array}$ & $\begin{array}{c}\text { S.D. of } \\
\text { Mean 1 }\end{array}$ & $\begin{array}{c}\text { S.D. of } \\
\text { Mean 2 }\end{array}$ & $\begin{array}{c}\text { Biological } \\
\text { repeat No. }\end{array}$ & P-value & Sig. \\
\hline $\mathbf{0 . 1}$ wt\% PVP-I & 23.9 & 35.6 & 0.45 & 0.09 & 3 & $<0.0001$ & $* * *$ \\
\hline $\mathbf{0 . 1}$ wt\% Citrimide & 23.9 & 37.2 & 0.45 & 0.12 & 3 & $<0.0001$ & $* * *$ \\
\hline $\begin{array}{l}\mathbf{0 . 1} \text { wt\% Benzylkonium } \\
\text { Chloride }\end{array}$ & 23.9 & 25.8 & 0.45 & 0.11 & 3 & 0.0021 & $* *$ \\
\hline $\begin{array}{l}\mathbf{0 . 1} \text { wt\% } \\
\text { Chlorohexynol }\end{array}$ & 23.9 & 31.1 & 0.45 & 1.03 & 3 & 0.0004 & $* * *$ \\
\hline
\end{tabular}




\section{Supporting Information}

\section{References}

(1) Smieja, M. Current Indications For The Use Of Clindamycin: A Critical Review. Canadian Journal of Infectious Diseases 1998, 9 (1), 22-28.

(2) Neonatal Formulary: Drug Use in Pregnancy and the First year of Life, John Wiley and Sons, Chichester, 2015.

(3) S. Padberg, in Drugs During Pregnancy and Lactation, ed. C. Schaefer, P. Peters and R. K. Miller, Academic Press, Cambridge, 3rd edn., 2015, vol. 1, ch. 2.6, 115-176.

(4) M. Rochon, A. Moussa and J. Autmizguine, in Infectious Disease and Pharmacology, ed. W. E. Benitz and P. B. Smith, Elsevier, Amsterdam, 2019, vol. 1, ch. 13, 155-166.

(5) T. Kuriyama, T. Karasawa and D. W. Williams, in Biofilms in Infection Prevention and Control, ed. S. L. Percival, D. W. Williams and T. Cooper, Academic Press, Cambridge, 2014, vol. 1, ch. 13, 209244.

(6) Hemani, M. L.; Lepor, H. Rev. Skin preparation for the prevention of surgical site infection: which agent is best? Urology, 2009, 11(4), 190-195.

(7) Eggers, M. Infectious Disease Management and Control with Povidone lodine. Infectious Diseases and Therapy, 2019, 8(4), 581-593.

(8) Bigliardi, P.; Langer, S.; Cruz, J. J.; Kim, S. W.; Nair, H.; Srisawasdi, G. An Asian Perspective on Povidone lodine in Wound Healing. Dermatology, 2017, 233, 223-233.

(9) Side Effects of Drugs Annual, Elsevier, Amsterdam, ${ }^{1 s t}$ edn., 2010.

(10)Vermeulen, H.; Westerbos, S.; Ubbink, D. Benefit And Harm Of lodine In Wound Care: A Systematic Review. Journal of Hospital Infection 2010, 76 (3), 191-199.

(11)Adverse Drug Reactions., Elsevier, Amsterdam, 1st edn., 2016.

(12)Lee, B.; Kim, S. Benzalkonium Chloride Induced Bronchoconstriction In Patients With Stable Bronchial Asthma. The Korean Journal of Internal Medicine 2007, 22 (4), 244.

(13)Braoudaki, M.; Hilton, A. Mechanisms Of Resistance In Salmonella Enterica Adapted To Erythromycin, Benzalkonium Chloride And Triclosan. International Journal of Antimicrobial Agents 2005, 25 (1), 31-37.

(14)Epstein, S.; Chen, D.; Asbell, P. Evaluation Of Biomarkers Of Inflammation In Response To Benzalkonium Chloride On Corneal And Conjunctival Epithelial Cells. Journal of Ocular Pharmacology and Therapeutics 2009, 25 (5), 415-424.

(15)Merchel Piovesan Pereira, B.; Tagkopoulos, I. Benzalkonium Chlorides: Uses, Regulatory Status, And Microbial Resistance. Applied and Environmental Microbiology 2019, 85 (13), 1-10. 


\section{Supporting Information}

(16)Marple, B.; Roland, P.; Benninger, M. Safety Review Of Benzalkonium Chloride Used As A Preservative In Intranasal Solutions: An Overview Of Conflicting Data And Opinions. Otolaryngology-Head and Neck Surgery 2004, 130 (1), 131-141.

(17)World health Organization, WHO Model Formulary, WHO press, Switzerland, 2008.

(18)Thomas, R.; Kotchevar, A. Comparativein Vitrometabolism Of Chloroxylenol, Chlorophene, And Triclosan With Rat, Mouse, And Human Hepatic Microsomes. Toxicological \& Environmental Chemistry 2010, 92 (9), 1735-1747.

(19)Orazi, G.; Ruoff, K.; O’Toole, G. Pseudomonas Aeruginosa Increases The Sensitivity Of BiofilmGrown Staphylococcus Aureus To Membrane-Targeting Antiseptics And Antibiotics. mBio 2019, 10 (4), 1-11.

(20)Gilbert, P.; McBain, A. Potential Impact Of Increased Use Of Biocides In Consumer Products On Prevalence Of Antibiotic Resistance. Clinical Microbiology Reviews 2003, 16 (2), 189-208.

(21)McDonnel, G.; Russell, A. D. Antiseptics and Disinfectants: Activity, Action, and Resistance. Clinical Microbiology Reviews, 2001, 14(1), 147-179.

(22)Lear, C. L.; Maillard, J.; Dettmar, P.W.; Goddard, P. A.; Russell, A. D. Chloroxylenol- and triclosantolerant bacteria from industrial sources. Journal of Industrial Microbiology and Biotechnology, $2002,29,238-242$.

(23)Vieira, D. Cationic Lipids And Surfactants As Antifungal Agents: Mode Of Action. Journal of Antimicrobial Chemotherapy 2006, 58 (4), 760-767. 